\title{
WEED INFESTATION AND BIODIVERSITY OF WINTER WHEAT UNDER THE EFFECT OF LONG-TERM CROP ROTATION
}

\author{
NIKOLIĆ, LJ. ${ }^{1}{ }^{*}$ - ŠEREMEŠIĆ, S. ${ }^{1}$ - MILOŠEV, D. ${ }^{1}$ - ĐALOVIĆ, I. ${ }^{2}$ - LATKOVIĆ, D. ${ }^{1}$ \\ ${ }^{1}$ Faculty of Agriculture, University of Novi Sad \\ Trg D. Obradovića 8, Novi Sad, Serbia \\ (phone: +381-21-485-3500; fax:+381-21-459-761) \\ ${ }^{2}$ Institute of Field and Vegetable Crops \\ Maksima Gorkog 30, Novi Sad, Serbia \\ (phone: +381-21-489-8100; fax:+381-21-662-1212) \\ *Corresponding author \\ e-mail: ljiljana.nikolic@polj.uns.ac.rs \\ (phone: +381-21-485-3453; fax:+381-21-454-442) \\ (Received $6^{\text {th }}$ Oct 2017; accepted $12^{\text {th }}$ Feb 2018)
}

\begin{abstract}
The paper presents the study of the floristic composition of weeds and weed infestation in winter wheat in long-term crop rotations at the experimental station near Novi Sad (Serbia). During the study period, a total of 48 weed species were determined, out of which 33 were determined in each study year. In two study years, there were 18 common species, while 15 species determined in 1991 were not found 19 years later. On the other hand, the study in 2010 recorded 15 new species that had not been previously found. The greatest floristic diversity ( 20 species) was found on fertilized four-year rotation in 1991 and unfertilized two-year rotation in 2010. The lowest diversity was recorded in 2010 on fertilized four-year rotation ( 9 species) and fertilized three-year rotation (10 species). The highest weed infestation was recorded in 1991 on unfertilized two-year rotation (2963 plants $\mathrm{m}^{-2}$ ) and unfertilized three-year rotation (2126 plants $\mathrm{m}^{-2}$ ), which is statistically significant compared to other variants. The lowest average weed infestation was observed in 2010 on fertilized three-year rotation (40 plants $\mathrm{m}^{-2}$ ) and fertilized four-year rotation $\left(53\right.$ plants $\left.\mathrm{m}^{-2}\right)$. Long-term crop rotations have a significant effect on the floristic composition and structure of weeds in winter wheat.
\end{abstract}

Keywords: weed, invasive plants, winter wheat, crop rotation

\section{Introduction}

Weeds, as highly adaptable plants, impede the implementation of planned cultivation practices in agricultural production. Therefore, finding adequate measures of weed control is a complex problem that requires a holistic approach (Avola et al., 2008). Weed control is a continuous process which includes a number of interrelated activities, the duration of which exceeds a single vegetation period. Preceding crops and the timing of tillage significantly affect the presence of weeds. In addition to common cultivation practices and applying agricultural chemicals, crop rotation has an important role in agricultural production because alternation of different crops has a beneficial effect on reducing weeds and establishing balance within an agroecosystem (Barberi et al., 1997; Suarez et al., 2001; Derksen et al., 2002; Anderson, 2005; Wozniak and Soroka, 2015). Balance in agroecosystems and in biodiversity directly affects sustainability of their structures and function (Oljača et al., 2014), which is one of the most important goals of contemporary agriculture.

In order to provide the necessary "biological minimum" for achieving high and stable yields in crop production, it is very important to ensure proper alternation of 
crops, taking into account self-tolerance and mutual tolerance of crops. Crop rotation is therefore given a great importance, also because it reduces the occurrence of plant diseases, pests and weeds (Molnar, 2003).

Due to significant effects of the year of growing (temporal effect) and the cultivation practice, it is very difficult to determine the cumulative contribution of crop rotation in weed control. Also, since in multi-year crop rotations phenological phases of cultivated crops and weeds overlap, these rotations reduce weed seedbank in the soil, which is particularly reflected in weed reduction in a subsequent period (Andersson and Milbereg, 1998; Teasdale et al., 2004).

In a long-term period, properly set crop rotations may have positive environmental impact on biodiversity conservation of the weed flora, as agricultural land is a typical habitat for certain segetal weeds, the survival of which is becoming more endangered, due to intensive agricultural practices (Hulina, 2005; Šilc, 2005). In order to identify the changes in weed flora, it is essential to study long-term crop rotations. Therefore, this research was based on the data obtained from the experiments established 70-40 years ago, in which we could determine the cumulative effects of crop rotation. The aim of this paper was to analyze the floristic composition and the intensity of weed infestation in winter wheat grown in different crop rotation and fertilization treatments over a period of nineteen years. The obtained results can be as a good basis for monitoring biodiversity of weeds in different crop rotations, but can also indicate the most favorable crop rotation treatment for weed reduction.

\section{Materials and methods}

\section{Weed survey and data collection}

In order to study long-term effects of different crop rotation and fertilization treatments on weed infestation of winter wheat crops, floristic surveys were conducted in 1991 and 2010 in field trials "Plodoredi" of the Institute of Field and Vegetable Crops in Novi Sad (Serbia) at the experimental station Rimski Šančevi $\left(45.19^{\circ} \mathrm{N}\right.$, $\left.19.50^{\circ} \mathrm{E}\right)$.

The weed flora was studied on the following variants of the experiment: unfertilized two-year and three-year rotations (MW and MWSo), established in 1946/47, two-year, three-year and four-year rotations with application of mineral fertilizers (MW-N, MWSo-N and MWSoSb-N), established in 1969/70, four-year rotation with application of mineral fertilizers (MWFW), established in 1950/51, and monoculture of wheat with applied mineral fertilizers (W-N), established in 1969/70.

The study was conducted on the Chernozem soil, which belongs to automorphic soil types, class A-C (humus-accumulative soils, the subtype of chernozem on loess and loess-like sediments, the carbonate chernozem variety, medium depth) (Škorić et al., 1986). The basic chemical soil properties are shown in Table 1. The method used for the analysis of organic matter content in soil samples is Tyrin's titrimetric method, in which a soil sample is oxidised with $0.2 \mathrm{M}$ potassium dichromate with sulphuric acid and heated to the boiling point for 5 minutes $\mathrm{DM}$ 8/1-3-017. Soil $\mathrm{pH}$ reaction was determined in a suspension with $\mathrm{H}_{2} \mathrm{O}$ and $1 \mathrm{M} \mathrm{KCl}$ (ratio of $1: 2.5$, w/v), using a Metrel MA3657 pH-meter, while the content of $\mathrm{CaCO}_{3}$ was determined volumetrically, by Scheibler's calcimeter; (Soil Survey Staff, 1993). Total nitrogen contents were determined with a CHNS analyzer (Elementar Vario EL, Germany). Determination of readily available phosphorus was performed by AL method (extraction with ammonium 
lactate) with spectrophotometric determination. Determination of readily available potassium was performed by AL method (extraction with ammonium lactate) followed by flame photometric determination.

The meteorological conditions, i.e. medium monthly temperatures and precipitations in two investigated years (1990/91 and 2009/10), according to meteorological station Rimski Šančevi, are shown in Figure 1.

The intensity of weed infestation was determined by the quantitative method of squares, i.e. by counting the number of weeds per $1 \mathrm{~m}^{2}$.

Weed sampling was done in relation to the phenological development of winter wheat according to decimal $\mathrm{BBCH}$ (Biologische Bundesanstalt, Bundessortenamt und Chemische Industrie) scale. The plants in all treatments of crop rotation were counted three times during the winter wheat growing season at beginnings of the development stages $\mathrm{BBCH} 30, \mathrm{BBCH} 53, \mathrm{BBCH} 85$, with 3 replications.

Weed species were determined according to Josifović (1970-1986) and Tutin et al. (1964-1980). The data were statistically accessed using the statistical software Statistica 12.

Table 1. Basic chemical soil properties on the experimental field (mean values $\pm S D$ )

\begin{tabular}{|c|c|c|c|c|c|c|c|}
\hline \multirow{2}{*}{ Year } & \multicolumn{2}{|c|}{ pH } & \multirow{2}{*}{$\underset{\%}{\mathrm{CaCO}}$} & \multirow{2}{*}{$\begin{array}{c}\text { Organic matter } \\
\%\end{array}$} & \multirow{2}{*}{$\begin{array}{c}\text { Total N } \\
\%\end{array}$} & \multirow{2}{*}{$\begin{array}{l}\mathrm{Al}-\mathrm{P}_{2} \mathrm{O}_{5} \\
\mathrm{mg} / 100 \mathrm{~g}\end{array}$} & \multirow{2}{*}{$\begin{array}{c}\mathrm{Al}-\mathrm{K}_{2} \mathrm{O} \\
\mathrm{mg} / 100 \mathrm{~g}\end{array}$} \\
\hline & in $\mathrm{KCl}$ & in $\mathrm{H}_{2} \mathrm{O}$ & & & & & \\
\hline 1991 & 7 & & & & 2 & & 38. \\
\hline 010 & $7.52 \pm 0.10$ & $8.1 \pm 0.12$ & $5.64 \pm 4.23$ & $2.7 \pm 0.38$ & $0.2 \pm 0.02$ & $65.93 \pm 61.50$ & $37.56 \pm 12.98$ \\
\hline
\end{tabular}

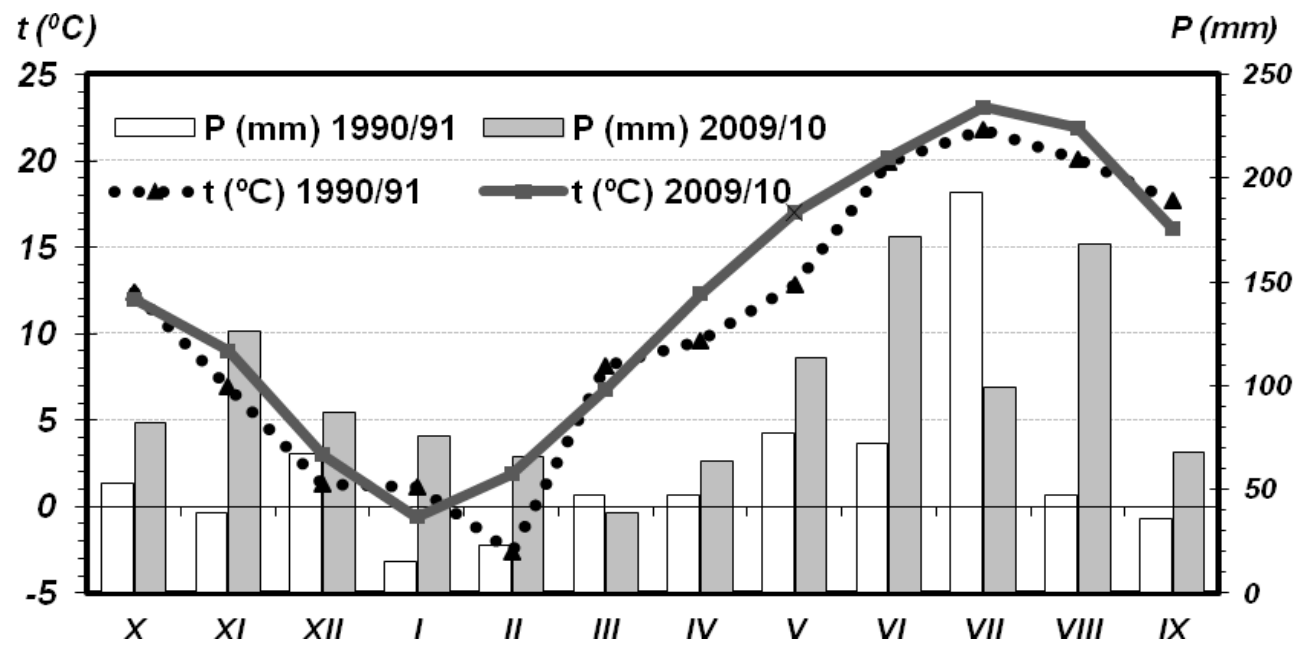

Figure 1. Medium monthly temperatures and precipitations in two production years (1990/91 and 2009/10)

\section{Treatments in the experiment}

The study included the following treatments: fertilized monoculture $(100 \%$ winter wheat) - W-N, fertilized two-year crop rotation (50\% maize and 50\% winter wheat) MW-N, fertilized three-year crop rotation (33.33\% maize, $33.33 \%$ soybean and $33.33 \%$ winter wheat) - MWSo-N, fertilized four-year crop rotation (25\% maize, $50 \%$ winter 
wheat and 25\% field peas) - MWFW-N, fertilized four-year crop rotation $333.33 \%$ maize, $33.33 \%$ winter wheat, $16.16 \%$ soybean and $16.16 \%$ sugar beet) - MWSoSb-N, unfertilized two-year crop rotation (50\% maize and 50\% winter wheat) - MW and unfertilized three-year rotation $(33.33 \%$ maize, $33.33 \%$ soybean and $33.33 \%$ winter wheat) - MWSo. The fertilized treatments included mineral nitrogen $(\mathrm{N})$ fertilizers at $100 \mathrm{~kg} \mathrm{ha}^{-1}$ rate for winter wheat $\left(50 \mathrm{~kg} \mathrm{ha}^{-1}\right.$ in autumn and $50 \mathrm{~kg} \mathrm{ha}^{-1}$ in spring). Phosphorus (P) and potassium (K) fertilization was based on soil analyses and was applied in autumn. Unfertilized two-year rotation (MW) and three-year rotation (MWSo) had not received any fertilization since 1946-1947, while crop residue incorporation started in 1986-1987. Cultivation of winter wheat was based on conventional tillage including moldboard plowing and seed bed preparation with a Kongskilde germinator. The sowing took place in October at a seeding rate of $250 \mathrm{~kg} \mathrm{ha}^{-1}$. Weed control in winter wheat started in 2000 with active matter 2.4D and iodosulfuron-methyl-sodium + amidosulfuron. Control of Sorghum halepense (L.) Pers. and other grass weeds was carried out by gliphosate each year in August after winter wheat harvest.

\section{Results}

\section{Composition of weed species}

The floristic composition of weeds and the intensity of weed infestation in winter wheat in different crop rotation treatments on the experimental field of the Institute of Field and Vegetable Crops (Serbia) in 1991 and 2010 are presented in Table 2.

In the floristic composition of the cropping systems in two study years there were a total of 48 plant species, out of which 33 species were determined in each study year. In two study years, 18 common species were identified, while 15 species were present only in the first study year and were not found 19 years later (marked with * in the table). On the other hand, the study in 2010 recorded 15 new species that had not been previously found (marked with ** in the table) (Table 2).

In all crop rotation treatments in 1991, the following weed species were constantly present: Polygonum convolvulus, Convolvulus arvensis, Lamium purpureum, Polygonum aviculare, Polygonum lapathifolium and Stellaria media. On the other hand, in the more recent study conducted in 2010, which included all wheat-based cropping systems, only three weed species were determined: Polygonum convolvulus, Consolida regalis and Veronica hederifolia. The species which was continuously present in both study years in all crop rotation treatments is Polygonum convolvulus (Table 2).

This paper analyzes floristic composition of weeds in different winter wheat systems of crop rotation and fertilization. The greatest floristic diversity (20 species) was found on fertilized four-year crop rotation (MWSoSb-N) in 1991 and unfertilized two-year rotation (MW) in 2010. Although floristic diversity in these two crop rotations was higher, it had no significant impact on the intensity of weed infestation in these crop rotations, which was 102 and 125 plants $\mathrm{m}^{-2}$, respectively. The floristic diversity was the lowest in 2010 on fertilized four-year rotation - MWSoSb-N (9 species), on which the intensity of weed infestation was also low, and on fertilized three-year rotation MWSo-N (10 species), which had the lowest intensity of weed infestation (Table 2; Fig. 2 and 3). Accordingly, it can be concluded that in all experiment wheat-based treatments, with the exception of unfertilized two-year rotation, there was a trend of a moderate decrease of floristic diversity over the period of 19 years (Table 2; Fig. 2). 
Table 2. Average infestation in wheat in different treatments of crop rotation 1991 and 2010 (no. ind. $\mathrm{m}^{-2}$ )

\begin{tabular}{|c|c|c|c|c|c|c|c|c|c|c|c|c|c|c|c|}
\hline \multirow{3}{*}{$\begin{array}{c}\text { EPPO } \\
\text { Code }\end{array}$} & \multirow{3}{*}{ Plant species } & \multicolumn{14}{|c|}{ Crop rotation } \\
\hline & & \multicolumn{2}{|c|}{$\mathbf{W}-\mathbf{N}$} & \multicolumn{2}{|c|}{ MW-N } & \multicolumn{2}{|c|}{ MW } & \multicolumn{2}{|c|}{ MWSo-N } & \multicolumn{2}{|c|}{ MWSo } & \multicolumn{2}{|c|}{ MWFW-N } & \multicolumn{2}{|c|}{ MWSoSb-N } \\
\hline & & 1991 & 2010 & 1991 & 2010 & 1991 & 2010 & 1991 & 2010 & 1991 & 2010 & 1991 & 2010 & 1991 & 2010 \\
\hline ADOAE & Adonis aestivalis L.** & & 0.44 & & & & & & & & & & & & 0.44 \\
\hline AGRRE & Agropyrum repens (L.) Beauv.* & & & 1.67 & & & & & & & & & & & \\
\hline AMBEL & Ambrosia artemisiifolia $\mathrm{L}$. & & & & & & 29.55 & & & & 77.77 & 0.11 & 2.66 & 0.08 & \\
\hline ANGRV & Anagallis arvensis $\mathrm{L}$. & & & 0.67 & & 809.33 & 0.44 & & & 708 & & & & 0.33 & \\
\hline ANGCO & Anagallis femina Mill.** & & & & & & 0.44 & & & & & & & & \\
\hline POLCO & Polygonum convolvulus (L.)Dum. & 40 & 59.11 & 98.67 & 25.66 & 310.33 & 2.22 & 33 & 5.33 & 109 & 2.22 & 42.66 & 15 & 30.42 & 6.21 \\
\hline CAPBP & Capsella bursa-pastoris (L.)Med. & & 31.11 & 1 & 0.44 & & 0.44 & & & 18 & & 0.11 & 1.77 & 0.08 & \\
\hline CUCLA & Caucalis daucoides L.* & 1 & & 1 & & & & & & & & & & & \\
\hline CENCY• & Centaurea cyanus L. & & 1.77 & & 0.88 & & & & & & & 1.66 & & & \\
\hline CHEAL & Chenopodium album L. & 10.33 & 0.44 & 9.33 & & & 0.44 & 50.33 & 4.88 & & & 13.11 & 10.21 & 26.58 & 9.33 \\
\hline CHEHY & Chenopodium hybridum L.** & & 0.44 & & 1.33 & & & & 1.77 & & & & 3.1 & & 0.44 \\
\hline CIRAR & Cirsium arvense (1.) Scop. & 0.33 & & & & & 2.22 & & & & & & & 0.08 & \\
\hline CNSRE• & Consolida regalis S.F. Gray. & & 110.64 & 3 & 45.77 & 66.67 & 3.10 & & 15.99 & & 0.44 & & 11.55 & & 8.44 \\
\hline CONAR & Convolvulus arvensis $\mathrm{L}$. & 8.67 & & 4.33 & & 24 & & 1 & 0.44 & 45.33 & & 8.89 & & 8.08 & \\
\hline DATST & Datura stramonium L.** & & & & & & & & 0.88 & & & & & & 2.66 \\
\hline EQUAR & Equisetum arvense L. ${ }^{*}$ & & & 0.33 & & 45.33 & & & & & & 0.22 & & & \\
\hline ERICA & Erigeron canadensis L.* & & & & & 274.67 & & & & 108 & & & & 2.25 & \\
\hline EPHCY & Euphorbia cyparissias L.* & & & 0.33 & & & & & & & & & & & \\
\hline EPHHE & Euphorbia helioscopia L.** & & & & & & 11.55 & & & & 12.44 & & & & \\
\hline FUMOF• & Fumaria officinalis L. & 16 & & 0.33 & 0.44 & & & & & 6.66 & & 4.78 & & 0.08 & \\
\hline GAETE & Galeopsis tetrahit $\mathrm{L}$. & & 0.11 & & 0.44 & 376 & & & & 213.33 & & & & & \\
\hline GALAP & Galium aparine $\mathrm{L}$. & 8.33 & 13.77 & 3.67 & 17.33 & & 4 & & & & & 0.11 & & 0.17 & \\
\hline HELTU & Helianthus tuberosus L.** & & & & & & & & 4.88 & & & & 3.11 & & \\
\hline
\end{tabular}




\begin{tabular}{|c|c|c|c|c|c|c|c|c|c|c|c|c|c|c|c|}
\hline LAMAM• & Lamium amplexicaule L.** & & 0.44 & & 1.33 & & & & & & & & 2.66 & & \\
\hline LAMPU & Lamium purpureum L.* & 4.67 & & 0.33 & & 20 & & 0.33 & & 188.66 & & 9 & & 0.33 & \\
\hline LTHTU• & Lathyrus tuberosus L.** & & & & 1.33 & & 1.33 & & & & 1.77 & & & & \\
\hline LITAR & Lithospermum arvense (L.) Vahl. & 1.33 & 0.88 & 1.67 & 0.88 & 210.67 & & & & & & & 0.44 & 0.33 & \\
\hline MEDLU & Medicago lupulina $\mathrm{L} . * *$ & & & & & & 1.33 & & & & & & & & \\
\hline OXAST & Oxalis stricta L.** & & & & & & 7.1 & & & & & & & & \\
\hline PAPRH • & Papaver rhoeas L. ** & & 14.88 & & 1.33 & & & & & & & & & & \\
\hline POAAN & Poa апnиа L.* & & & & & & & & & 2.66 & & & & & \\
\hline POLAV & Polygonum aviculare L. & 13.33 & & 8.67 & & 28.67 & 2.66 & 1.33 & & 58 & 5.33 & 0.11 & & 12.58 & 0.88 \\
\hline POLLA & Polygonum lapathifolium L.* & 7.75 & & 13.67 & & 19.67 & & 1.33 & & 19 & & 23.78 & & 8.33 & \\
\hline RANAR • & Ranunculus arvensis L.** & & & & & & 0.64 & & & & & & & & \\
\hline RHIAG & Rhinanthus major Ehrh.* & & & & & & & & & 122.66 & & & & & \\
\hline SAMEB & Sambucus ebulus L.* & & & & & & & 2.66 & & & & & & 0.33 & \\
\hline SETVI & Setaria viridis (L.) Beauv.* & & & & & 148 & & & & 124 & & & & & \\
\hline SINAR & Sinapis arvensis L. & & 0.44 & & & 5.33 & 44 & & & 16 & 72.74 & & 9.77 & & \\
\hline SOLNI & Solanum nigrum L.** & & & & 0.88 & & 1.77 & & 0.44 & & 1.33 & & & & \\
\hline SONOL & Sonchus oleraceus (L.) Gou.* & & & & & 5.33 & & & & & & & & & \\
\hline SORHA & Sorghum halepense (L.) Pers.** & & & & & & 10.22 & & 3.55 & & 7.55 & & & & 0.44 \\
\hline STAAN & Stachys anпиа L.** & & & & & & & & & & 1.33 & & & & \\
\hline STEME & Stellaria media (L.) Vill. & 30 & & 33.67 & & 320 & 0.88 & 5.33 & & 156.66 & 15.55 & 85.44 & & 8.42 & \\
\hline TAROF & Taraxacum officinale Weber.* & 3.33 & & & & 32 & & 17.66 & & 130.66 & & & & 2.83 & \\
\hline TRFRE & Trifolium repens L.* & & & & & 85.33 & & & & 8 & & & & 0.42 & \\
\hline VERHE & Veronica hederifolia $\mathrm{L}$. & 0.33 & 256 & & 87.55 & & 0.44 & & 1.77 & & 0.44 & 3.11 & 40.88 & & 23.99 \\
\hline VICVI & Vicia vilosa Roth.* & & & & & 178.67 & & 0.33 & & 91.33 & & 0.66 & & 0.08 & \\
\hline \begin{tabular}{l|l|} 
VIOAR • \\
\end{tabular} & Viola arvensis Murr. & 14 & & 1.67 & 0.44 & 2.67 & & 1.66 & & & & & & 0.33 & \\
\hline \multicolumn{2}{|c|}{ Total number of plant species } & 15 & 14 & 18 & 15 & 19 & 20 & 12 & 10 & 18 & 12 & 15 & 11 & 20 & 9 \\
\hline \multicolumn{2}{|c|}{ Average number of ind. $\mathrm{m}^{-2}$} & 159 & 491 & 184 & 186 & 2963 & 125 & 115 & 40 & 2126 & 199 & 194 & 101 & 102 & 53 \\
\hline
\end{tabular}

APPLIED ECOLOGY AND ENVIRONMENTAL RESEARCH 16(2):1413-1426.

http://www.aloki.hu • ISSN 15891623 (Print) • ISSN 17850037 (Online)

DOI: http://dx.doi.org/10.15666/aeer/1602_14131426

๔ 2018, ALÖKI Kft., Budapest, Hungary 


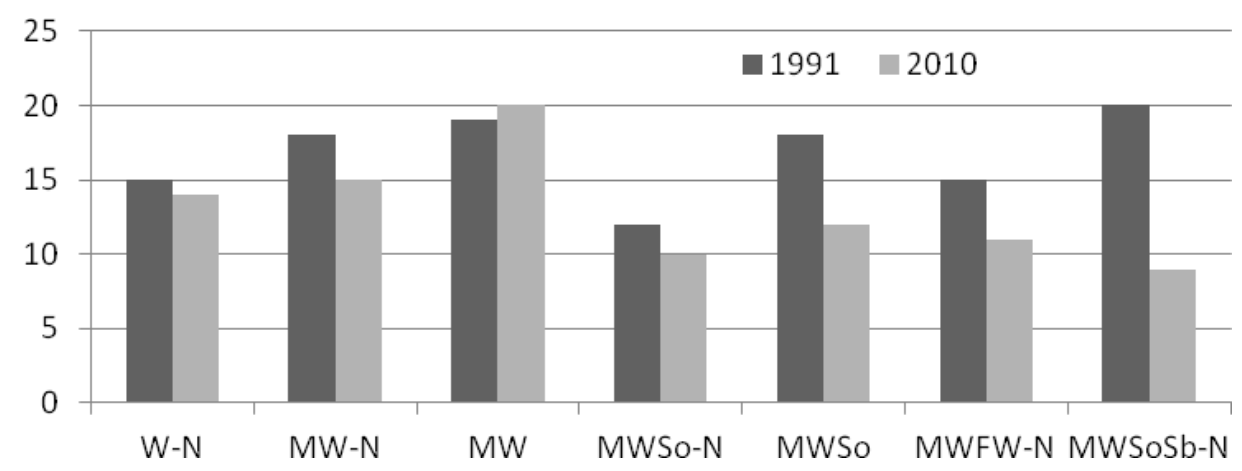

Figure 2. Number of weed species in different treatments of crop rotation

\section{Weed infestation in winter wheat}

With regard to the intensity of infestation, extremely high weed infestation was recorded in 1991 on unfertilized two-year and three-year rotations - 2963 and 2126 plants $\mathrm{m}^{-2}$, respectively. The difference between weed infestation in these two treatments and other crop rotation treatments is statistically significant or highly significant (Tables 2 and 3; Fig. 3). Such high levels of weed infestation on unfertilized rotations could be accounted for by a high number of weeds in the seedling stage in the very first stages of wheat vegetative growth, by the preceding crop (maize, soybean), which was favorable for weed infestation, and by the absence of fertilization, which in these treatments provided for better competitiveness of weeds compared to winter wheat. The lowest average weed infestation in winter wheat crops was recorded in the second study year, 19 later, on fertilized three-year rotation and four-year rotation (MWSoSb-N), on which there were 40 and 53 plants $\mathrm{m}^{-2}$, respectively (Table 2; Fig. 3).

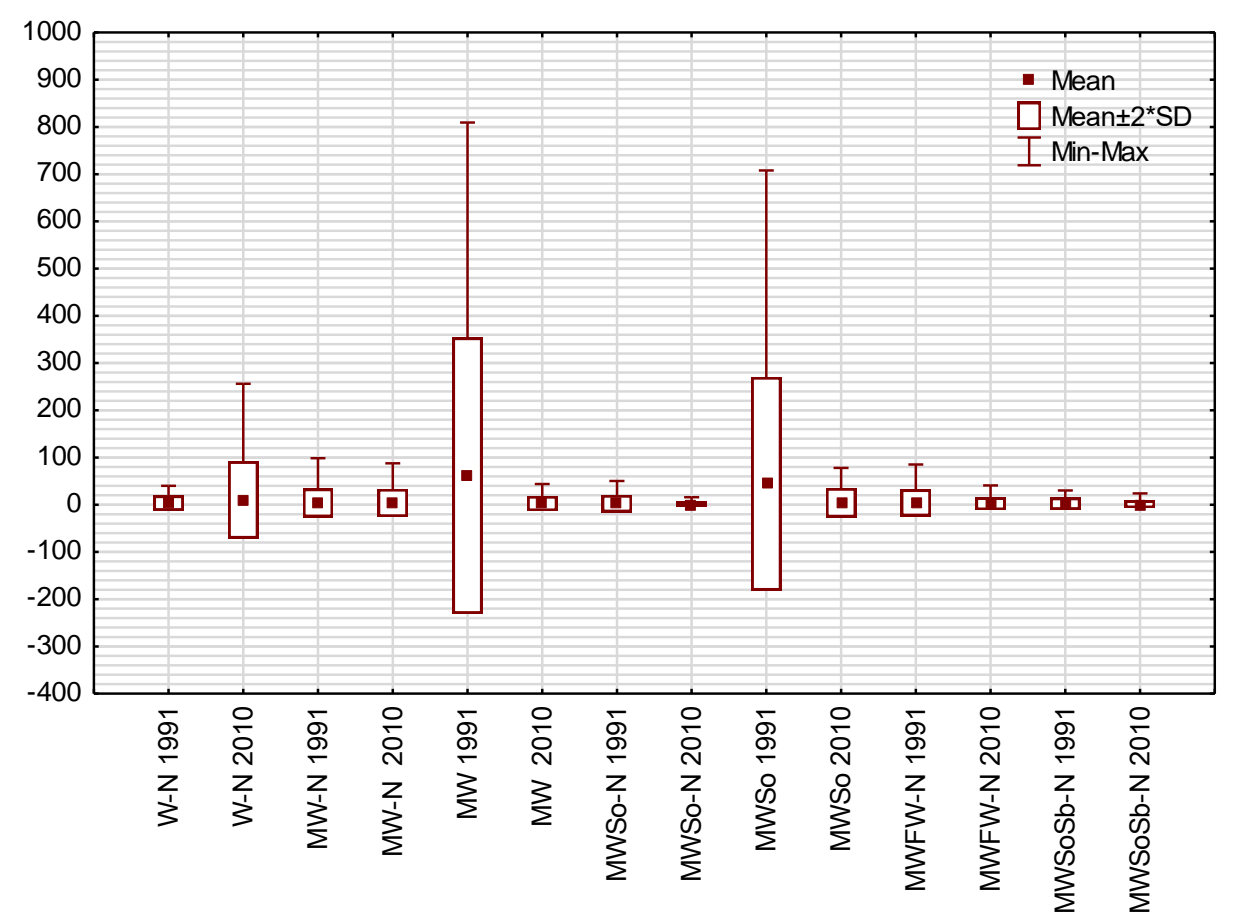

Figure 3. Weed infestation in winter wheat in different treatments of crop rotation (no. ind. $\mathrm{m}^{-2}$ ) 


\section{Trends in changes of weed infestation}

Table 4 shows the changes in the average weed infestation observed over time between certain crop rotation systems. It can be observed that over the period of 19 years in winter wheat monoculture there was a prominent trend of increasing weed infestation by even $68 \%$, while on fertilized two-year rotation there was a relatively unchanged level of weed infestation with only a minor increase of $1 \%$, which could be accounted for by the cumulative effect of crop rotation on the number of weeds. However, in other crop rotation treatments there was a prominent trend of reducing weed infestation after the period of 19 years.

\section{Weed species significant for biodiversity}

This study determined the presence of a number of invasive species, including Ambrosia artemisiifolia, Helianthus tuberosus, Datura stramonium, Erigeron canadensis and Sorghum halepense (Table 2). These species were more prominent only in the treatments of unfertilized two-year and three-year crop rotations, which could be affected also by the preceding crop, among which these weeds usually proliferate. Ambrosia artemisiifolia is of particular interest as it is invasive both at the local and global level (DAISIE - Delivering Alien Invasive Species Inventories for Europe, EPPO - European and Mediterranean Plant Protection Organization, GISD Global Invasive Species Database), while Helianthus tuberosus is invasive at the European level (DAISIE, EPPO). The other three species (D. stramonium, E. canadensis and $S$. halepense) are on the list of invasive weeds in Serbia (Lazarevic et al., 2012). It is encouraging that the invasive species in the studied crop rotations were not too numerous and did not contribute substantially to the overall weed infestation of winter wheat in the study period, with the exception of E. canadensis in 1991 on unfertilized two-year rotation $\left(274.67\right.$ plants $\left.\mathrm{m}^{-2}\right)$ and unfertilized three-year rotation (108 plants $\left.\mathrm{m}^{-2}\right)$ and A. artemisifolia $\left(77.77\right.$ plants $\mathrm{m}^{-2}$ ) only in 2010 on unfertilized three-year rotation.

With regard to biodiversity conservation, on the other hand, it is necessary to stress the presence of threatened weeds according to Hulina (2005) (Table 2, marked with •). From the category of endangered weed species, there was $F$. officinalis, which in the studied crop rotation treatments decreased in number in the second study year by $80 \%$. From the category of vulnerable weed species, there were seven species, three of which (C. cyanus, $C$. regalis and $V$. arvensis) were present in both study periods, while four species (L. amplexicaule, L. tuberosus, $P$. rhoeas and $R$. arvensis) appeared only in 2010. The presence of $V$. arvensis from the category of vulnerable species also declined by $80 \%$ over the peiod of 19 years. The treatment of fertilized two-year rotation proved to be favorable for survival of the endangered species $F$. officinalis and the vulnerable species $V$. arvensis.

\section{Discussion}

The composition of weed flora in a certain crop is determined by the existing environmental conditions as well as applied cultural practices. This study was conducted in the winter wheat to determine the presence of different weed species in the same treatments of crop rotation for two study periods. Based on the comparative analysis of the soil properties from 1991 and 2010 (Table 1), the most significant 
change was recorded for the organic matter content (Seremesic et al., 2017). This change can be accounted for by introduction of more productive varieties and hybrids and by plowing in of plant residues. The cumulative effect of crop rotation had an impact on the observed soil properties, which indirectly had an impact also on the floristic composition and structure of the weeds. Despite certain differences between the studied years in terms of meteorological indicators (Fig. 1) and application of herbicides in the entire studied area (from 2000), the presence of different species, i.e. disappearance of certain species and appearance of new ones could be attributed to the effects of crop rotation on weed flora diversity, which is consistent with the results of previous research (Andersson and Milbereg, 1998; Suarez et al., 2001; Derksen et al., 2002; Moss et al., 2004; Anderson, 2005; Kovačević et al., 2007; De Mol et al., 2015).

In the first study year, seven species were constantly present in all treatments of crop rotation (Polygonum convolvulus, Convolvulus arvensis, Lamium purpureum, Polygonum aviculare, Polygonum lapathifolium and Stellaria media), while 19 years later only three weed species were constantly present in all crop rotations (Polygonum convolvulus, Consolida regalis and Veronica hederifolia). The only constantly present species in both study years in all crop rotations was Polygonum convolvulus (Table 2). These weed species were found to have the greatest impact on the increasing intensity of weed infestation in certain experiment treatments. All these species, except for Convolvulus arvensis which belongs to geophytes, are therophytes, the predominance of which in cropland indicates instability of the weed community because of applied agricultural practices (Kovačević, 2007; Milošev et al., 2009; Nikolić et al., 2012).

Biodiversity of an ecosystem is a reflection of the existing conditions in it and its balance. Although contemporary crop production leads to uniformity of agroecosystems at all levels, it should be noted that different crop production systems do not equally affect the level of biodiversity. There is an increasing trend of using crop production systems that favor increasing biodiversity as a necessary prerequisite in raising productivity and protecting agroecosystems, while special role in these systems is given to crop rotation, through which biodiversity is increased over time (Oljača, 2013). The system of crop rotation generates special environmental conditions that do not aim to reduce weed flora diversity, but rather to prevent excessive occurrence of certain weed species that could cause considerable yield loss to a particular crop (Barberi et al., 1997; Wozniak and Soroka, 2015). Accordingly, this paper analyzes also the floristic composition of weeds in winter wheat cultivated in different systems of crop rotation and fertilization. The greatest floristic diversity (20 species) was found on fertilized four-year crop rotation (MWSoSb-N) in 1991 and unfertilized two-year rotation (MW) in 2010 (Table 2). Although these two crop rotation treatments had higher floristic diversity, it had no significant impact on the intensity of weed infestation of these crop rotations, which was 102 and 125 plants $\mathrm{m}^{-2}$, respectively, according to the results of previous research (Nikolić et al., 2016).

It can be concluded that in our agroecological conditions, three-year crop rotation with the use mineral fertilizers proved to be the most beneficial for reduction of weeds. Milošev et al. (2014) identified three-year wheat-based rotation as the most favorable also in terms of the optimal use of production conditions and the lowest negative impact on the environment. The analysis of weed infestation in two study years indicates that the differences were statistically highly significant ( $\mathrm{p}=0.00 * *$ ), which also demonstrates the positive effects of long-term crop rotation on weed reduction in winter wheat. 
Table 3. The significance of differences in the number of weed individuals per $\mathrm{m}^{2}$ between different treatments of crop rotation

\begin{tabular}{|c|c|c|c|c|c|c|c|c|c|c|c|c|c|c|c|}
\hline & \multicolumn{3}{|c|}{$\mathbf{W}-\mathbf{N}$} & \multicolumn{2}{|c|}{ MW-N } & \multicolumn{2}{|c|}{ MW } & \multicolumn{2}{|c|}{ MWSo-N } & \multicolumn{2}{|c|}{ MWSo } & \multicolumn{2}{|c|}{ MWFW-N } & \multicolumn{2}{|c|}{ MWSoSb-N } \\
\hline & & 1991 & 2010 & 1991 & 2010 & 1991 & 2010 & 1991 & 2010 & 1991 & 2010 & 1991 & 2010 & 1991 & 2010 \\
\hline \multirow{2}{*}{$\mathbf{W}-\mathbf{N}$} & 1991 & & & & & $0.0068^{* *}$ & & & $0.0413^{*}$ & $0.0138^{*}$ & & & & & \\
\hline & 2010 & & & & & $0.0207^{*}$ & & & & & & & & & \\
\hline \multirow{2}{*}{ MW-N } & 1991 & & & & & $0.0075^{* *}$ & & & & $0.0156^{*}$ & & & & & \\
\hline & 2010 & & & & & $0.0076^{* *}$ & & & & $0.0157^{*}$ & & & & & \\
\hline \multirow{2}{*}{ MW } & 1991 & $0.0068^{* *}$ & $0.0207^{*}$ & $0.0075^{* *}$ & $0.0076^{* *}$ & & $0.0062^{* *}$ & $0.0061^{* *}$ & $0.0048^{* *}$ & & $0.0079^{* *}$ & $0.0077^{* *}$ & $0.0058^{* *}$ & $0.0058^{* *}$ & $0.005^{\text {** }}$ \\
\hline & 2010 & & & & & $0.0062^{* *}$ & & & & $0.0123^{*}$ & & & & & \\
\hline \multirow{2}{*}{ MWSo-N } & 1991 & & & & & $0.0061^{* *}$ & & & & $0.0119^{*}$ & & & & & \\
\hline & 2010 & $0.0413^{*}$ & & & & $0.0048^{* *}$ & & & & $0.009^{* *}$ & & & & & \\
\hline \multirow{2}{*}{ MWSo } & 1991 & $0.0138^{*}$ & & $0.0156^{*}$ & $0.0157^{*}$ & & $0.0123^{*}$ & $0.0119^{*}$ & $0.009^{* *}$ & & $0.0165^{*}$ & $0.016^{*}$ & $0.0113^{*}$ & $0.0113^{*}$ & $0.0094^{* * *}$ \\
\hline & 2010 & & & & & $0.0165^{*}$ & & & & & & & & & \\
\hline \multirow{2}{*}{ MWFW } & 1991 & & & & & $0.0077^{* *}$ & & & & $0.016^{*}$ & & & & & \\
\hline & 2010 & & & & & $0.0058^{* *}$ & & & & $0.0113^{*}$ & & & & & \\
\hline \multirow{2}{*}{ MWSoSb-N } & 1991 & & & & & $0.0058^{* *}$ & & & & $0.0113^{*}$ & & & & & \\
\hline & 2010 & & & & & $0.0050^{* *}$ & & & & $0.0094^{* *}$ & & & & & \\
\hline
\end{tabular}

Legend: Values marked with asterisks are significantly at $\mathrm{p}<0.05\left(^{*}\right)$ and $\mathrm{p}<0.01\left(^{* *}\right)$ levels, empty - non significant

Table 4. Review of weed infestation of wheat and trend of changes

\begin{tabular}{|c|c|c|c|c|}
\hline \multirow{3}{*}{ Crop rotation } & \multicolumn{2}{|c|}{ Year } & \multirow{3}{*}{$\begin{array}{l}\text { Trend of changes } \\
\quad\left(\text { no. ind. } \mathrm{m}^{-2}\right)\end{array}$} & \multirow{3}{*}{$\begin{array}{l}\text { Trend of changes } \\
(\%)\end{array}$} \\
\hline & 1991 & 2010 & & \\
\hline & Average (no. ind. $\mathrm{m}^{-2}$ ) & Average (no. ind. $\mathrm{m}^{-2}$ ) & & \\
\hline $\mathbf{W}-\mathbf{N}$ & 159 & 491 & +332 & +68 \\
\hline MW-N & 184 & 186 & +2 & +1 \\
\hline MW & 2963 & 125 & -2838 & -96 \\
\hline MWSo-N & 115 & 40 & -75 & -65 \\
\hline MWSo & 2126 & 199 & -1927 & -91 \\
\hline MWFW & 194 & 101 & -93 & -48 \\
\hline MWSoSb-N & 102 & 53 & -49 & -48 \\
\hline
\end{tabular}

APPLIED ECOLOGY AND ENVIRONMENTAL RESEARCH 16(2):1413-1426.

http://www.aloki.hu • ISSN 15891623 (Print) • ISSN 17850037 (Online)

DOI: http://dx.doi.org/10.15666/aeer/1602_14131426

๑ 2018, ALÖKI Kft., Budapest, Hungary 
In all other crop rotations (except for the monoculture and fertilized two-year rotation) during the 19-year period there was a strong trend of weed reduction, which is in accordance with a number of other studies (Andersson and Milbereg, 1998; Smith and Gross, 2007). The results show that the intensity of weed infestation was reduced by $48 \%$ on fertilized four-year rotation (MWSoSb-N) and fertilized four-year rotation (MWFW $-\mathrm{N}$ ), by $65 \%$ on fertilized three-year rotation and even by $91 \%$ on unfertilized three-year rotation and $96 \%$ on unfertilized two-year rotation (Table 4).

The presence of invasive species in a certain area indicates the onset of secondary succession influenced by various factors, including ecological factors (climatic, edaphic, etc.), applied cultivation practices, the type of crops, the preceding crop, the historical factor, etc. (Czárán and Bartha, 1990; Pickett et al., 2001). Studying the interaction between individual factors and occurrence of invasive species is very complex and it is not included in this research, which is only to determine the presence of these species. In the contemporary floristic research of agroecosystems, it is of great importance to monitor occurrence and expansion of invasive plant species (Ziska et al., 2011; Chikuruwo et al., 2017). Although invasive plant species were not present in large numbers in the second study period, it is necessary to monitor their presence and abundance because of potential threats to biodiversity and functioning of ecosystems in case of their unexpected spreading (Chytrý et al., 2005; Pink and Pal, 2009; Kenis et al., 2012).

Due to the application of total herbicides after the winter wheat harvest, most of the invasive weeds were successfully controlled, and it can be assumed that the presence of maize and soyabean in the unfertilized treatments had greater impact than the presence of winter wheat on the number of weeds. In drier years the number of invasive weeds can be expected to increase. The study years in this research, on the other hand, were considered as normal production years in terms of temperature and precipitation. When assessing the occurrence of certain weed species, however, the priority should be given to environmental factors (geographical location, climate and soil type), then to crop management factors, and only then to the factor of "the year" (Hallgren et al., 1999; De Mol et al., 2015).

On the other hand, besides monitoring the presence of invasive weed species because of their importance for biodiversity conservation of agroecosystems according to the action plan (The 2001 Biodiversity Action Plan for Agriculture /COM/2001/0162), it is important also to determine the presence of the weed species (Table 2, marked with $\bullet$ ) that, according to Hulina (2005), are already categorized as endangered or vulnerable in the neighboring region of Croatia, according to the categories of IUCN Red List (Walter and Giller, 1998).

Although one endangered species ( $F$. officinalis) and one vulnerable species ( $V$. arvensis) showed a decreasing trend, after the 19-year period no species from these categories disappeared. Moreover, after the period of 19 years four new species from the category of vulnerable species appeared (L. amplexicaule, L. tuberosus, P. rhoeas and $R$. arvensis). It can be concluded that the wheat crop grown in crop rotations provides for the survival of these weed species, which in very similar neighboring agroecosystems have already been identified as endangered and vulnerable, as survival of these species is the most certain in conditions of the agroecosystems.

In the long term, diversity of crops in crop rotations without external chemical inputs results in changes of soil properties (Van Eerd et al., 2013) that do not lead to increasing of weeds, nor to the development of weed communities that are difficult to control (Smith and Gross, 2007). Use of crop rotation is also justified in terms of environmental 
protection and sustainability of agroecosystems, since it leads to reduced use of chemical substances. Intensive application of pesticides has resulted in high levels of pesticide residues in the soil and groundwater and has reduced beneficial insects and fauna. People have become concerned about pesticide residues entering food chains and affecting human health. Short rotations, especially monocultures, have increased soil erosion and reduced biological diversity (Molnar, 2003).

\section{Conclusions}

Based on the results obtained in this study carried out over the period of 19 years, it can be concluded that cultivation of winter wheat in long-term crop rotations has a significant effect on the floristic composition and structure of weeds, without causing significant development of invasive plant species (Table 2). Also, there was a marked trend of decreasing wheat infestation in crop rotations (Table 4), which is of particular importance from the aspect of sustainable and environmentally friendly agriculture. A good indicator of this trend is the treatment of wheat monoculture, where despite the application of herbicides, after nineteen years there was a marked trend of increasing weed infestation compared to other treatments of crop rotation in the same agroecological conditions.

In the continuation of the research, it is planned to further analyze the ecological indices of weed species taking into account the meteorological and soil conditions of the studied area, in order to provide a more comprehensive understanding of the trend of succession changes of the weed flora in the conditions of long-term crop rotation.

Acknowledgement. We are grateful to the Institute of Field and Vegetable Crops in Novi Sad for allowing us to work in their fields "Plodoredi".

\section{REFERENCES}

[1] Anderson, L. R. (2005): A multi-tactic approach to manage weed population dynamics in crop rotation. - Agronomy Journal 97: 1579-1583.

[2] Andersson, N. T., Milberg, P. (1998): Weed flora and the relative importance of site, crop, crop rotation, and nitrogen. - Weed Science 46(1): 30-38.

[3] Avola, G., Tuttobene, R., Gresta, F., Abbate, V. (2008): Weed control strategies for grain legumes. - Agronomy of Sustainable Development 28(3): 389-395.

[4] Barberi, P., Silvestri, N., Bonari, E. (1997): Weed communities of winter wheat as influenced by input level and rotation. - Weed Research 37: 301-313.

[5] Chikuruwo, C., Masocha, M., Murwira, A., Ndaimani, H. (2017): Predicting the suitable habitat of the invasive Xanthium strumarium in southeastern Zimbabwe. - Applied Ecology and Environmental Research 15(1): 17-32.

[6] Chytrý, M., Pyšek, P., Tichý, L., Knollová, I., Danihelka, J. (2005): Invasions by alien plants in the Czech Republic, a quantitative assessment across habitats. - Preslia 77: 339354.

[7] Czárán, T., Bartha, S. (1990): The Effect of Spatial Pattern on Community Dynamics: A Comparison of Simulated and Field Data. - In: Grabherr, G., Mucina, L., Dale, M. B., Ter Braak, C. J. F. (eds.) Progress in Theoretical Vegetation Science. Advances in Vegetation Science, Vol. 11, pp. 229-239. Springer, Dordrecht.

[8] De Mol, F., Von Redwitz, C., Geroeitt, B. (2015): Weed species composition of maize fields in Germany is influenced by site and crop sequence. - Weed Research 55: 574-585. 
[9] Derksen, A. D., Andersen, L. R., Blackshaw, E. R., Maxwell, B. (2002): Weed dynamics and management strategies for cropping systems in the Northern Great Plains. Agronomy Journal 94: 174-185.

[10] Hallgren, E., Palmer, M., Milberg, P. (1999): Data diving with cross-validation: an investigation of broad-scale gradients in Swedish weed communities. - Journal of Ecology 87: 1037-1051.

[11] Hulina, N. (2005): List of threatened weeds in continental part of Croatia and their possible conservation. - Agriculturae Conspectus Scientificus 70(2): 37-42.

[12] Josifović, M. (ed.) (1970-1986): Flora Republike Srbije, I-X. - SANU, Beograd.

[13] Kenis, M., Bache, S., Baker, R. H. A., Branquart, E., Brunel, S., Holt, J. et al. (2012): New protocols to assess the environmental impact of pests in the EPPO decision-support scheme for pest risk analysis. - Bulletin OEPP/EPPO 42(1): 21-27.

[14] Kovačević, D., Dolijanović, Ž., Milić, V. (2007): The influence of the soil treatment system on wheat's weed /Uticaj sistema obrade zemljišta na korovsku sinuziju ozime pšenice. - Journal of Scientific Agricultural Research 68(243): 85-94 (in Serbian with English abstract).

[15] Lazarević, P., Stojanović, V., Jelić, I., Perić, R., Krsteski, B., Ajtić, R. et al. (2012): Preliminary list of invasive species in the Republic of Serbia/Preliminarni spisak invazivnih vrsta u republici Srbiji sa opštim merama kontrole i suzbijanja kao potpora budućim zakonskim aktima. - Protection of nature 62(1): 5-31 (in Serbian with English abstract).

[16] Milošev, D., Šeremešić, S., Nikolić, Lj., Knežević, A., Đalović, I., Vuga-Janjatov, V. (2009): Floristic composition and structure of weed flora in long-term winter wheat cropping systems. - Herbologia 10(1): 31-41.

[17] Milošev, D., Šeremešić, S., Đalović, I., Pejić, B., Ćirić, V. (2014): Assessing the agroecosystem performance in a long-term winter wheat croopping. - Contemporary Agriculture 63(4-5): 494-500.

[18] Molnar, I. (2003): Cropping systems in Eastern Europe, past, present and future. Journal of Crop Production 9: 623-647.

[19] Moss, R. S., Storkey, J., Cussans, W. J., Perryman, A. M. S., Hewitt, V. M. (2004): Simposium the broadbalk long-term experiment at Rothamsted, what has it told us about weeds? - Weed Science 52: 864-873.

[20] Nikolić, Lj., Milošev, D., Šeremešić, S., Latković, D., Červenski, J. (2012): Diversity of weed flora in conventional and organic agriculture. - Acta Herbologica 21(1): 13-20 (in Serbian with English abstract).

[21] Nikolić, Lj., Šeremešić, S., Milošev, D., Đalović, I. (2016): Weed Infestation of Wheat and Maize in Crop Rotations/Zakorovljenost pšenice i kukuruza u uslovima plodoreda. Paper presented at the 10th Weed Science Congress, 21-23 September, Vrdnik, Serbia. In: Janjić, V. (ed.) Proceedings of 10th Weed Science Congress (pp. 50). Serbian Weed Science Society, Beograd, Serbia (in Serbian with English abstract).

[22] Oljača, S., Kovačević, D., Dolijanović, Ž., Milić, V. (2014): Organic Agriculture in Terms of Sustainable Development of Serbia. - Paper presented at the Fifth International Scientific Agricultural Symposium „Agrosym 2014, 6-9 October, Jahorina, Bosnia and Herzegovina (in Serbian with English abstract).

[23] Pickett, S. T. A., Cadenasso, M. L., Bartha, S. (2001): Implications from the Buell-Small Succession Study for vegetation restoration. - Applied Vegetation Science 4(1): 41-52.

[24] Pinke, G., Pál, R. (2009): Floristic composition and conservation value of the stubblefield weed community, dominated by Stachys annua in western Hungary. - Biologia 64(2): 279-291.

[25] Seremesic, S., Ćirić, V., Milošev, D., Vasin, J., Djalovic, I. (2017): Changes in soil carbon stock under the wheat-based cropping systems at Vojvodina province of Serbia. Archives of Agronomy and Soil Science 63(3): 388-402. 
[26] Šilc, U. (2005): Weed vegetation of the northern part of Ljubljansko polje. - Hacquetia 4(2): 161-171.

[27] Škorić, A., Filipovski, G., Ćirić, M. (1985): Klasifikacija zemljišta Jugoslavije. Akademija nauke i umetnosti BiH. - Posebna izdanja, knjiga LXXVIII, Sarajevo, SR Jugoslavija.

[28] Smith, R. G., Gross, L. K. (2007): Assembly of weed communities along a crop diversity gradient. - Journal of Applied Ecology 44(5): 1046-1056.

[29] Suarez, A. S., De la Fuente, B. E., Ghersa, M. C., Leon, J. C. R. (2001): Weed community as an indicator of summer crop yield and site quality. - Agronomy Journal 93: 524-530.

[30] Teasdale, R. J., Mangum, W. R., Radhakrishnan, J., Cavigelli, A. M. (2004): Weed seedbank dynamics in three organic farming crop rotations. - Agronomy Journal 96: 1429-1435.

[31] Tutin, G., Heywood, V. H., Burges, N. A., Valentine, D. H., Walters, S. M., Webb, D. A. (eds.) (1964-1980): Flora Europea, 1-5. - University Press, Cambridge.

[32] Van Eerd, L. L., Congreves, A. K., Hayes, A., Verhallen, A., Hooker, C. D. (2014): Long-term tillage and crop rotation effects on soil quality, organic carbon, and total nitrogen. - Canadian Journal of Soil Science 94(3): 303-315.

[33] Ziska, H. L., Blumenthal, M. D., Runion, G. B., Hunt, Jr. R., Diaz-Soltero, H. (2011): Invasive species and climate change: an agronomic perspective. - Climate Change 105: 13-42.

[34] Woźniak, A., Soroka, M. (2015): Structure of weed communities occuring in crop rotation and monoculture of cereals. - International Journal of Plant Production 9(3): 487-506.

[35] Walter, K. S., Giller, H. J. (eds.) (1998. 1997): IUCN Red List of Threatened Plants. Compilated by World Conservation Monitoring Centre. IUCN - The Conservation Union, Gland, Switzerland and Cambridge, UK. 